\title{
ABUNDANCE OF THE ALIEN SPIONID STREBLOSPIO GYNOBRANCHIATA IN RELATION TO SEDIMENT COMPOSITION ALONG THE SOUTHERN COAST OF THE CASPIAN SEA
}

\author{
Amir Faraz GHASEMI *, Armin JAM **, Mehrshad TAHERI ** and Maryam FOSHTOMI ** \\ * Khorramshahr Marine Science and Technology University, Faculty of Marine Science and Oceanography, P.O. Box \\ 64199-669, Khorramshahr, Khozestan, IR-64199-43175, Iran, faraz_ghasemi@yahoo.com \\ ** Iranian National Institute for Oceanography, Etemad Zadeh Street 9, Tehran, Iran, IR-1411813389, \\ jamrmin@yahoo.com, mehrshadtaheri@yahoo.com, maryam.yazdanifoshtomi@ugent.be
}

DOI: 10.1515/trser-2015-0020

KEYWORDS: density, Streblospio gynobranchiata, total organic matter, sediment. ABSTRACT

Seasonal and inter-annual variations in the density of the invasive polychaete Streblospio gynobranchiata were noted in the south Caspian Sea when sediment conditions were examined at five and 14 meters depths in 2005 and 2010. There was no clear trend in changing density in line one but in line two, in all seasons except summer, density of $S$. gynobranchiata decreased significantly. Maximum densities of $2,040 \mathrm{ind} . / \mathrm{m}^{-2}$ and 1,013 ind. $/ \mathrm{m}^{-2}$ were obtained in 2005 and 2010, respectively. Although the percentage of total organic matter as a food resource increased from 2005 to 2010, the density of $S$. gynobranchiata decreased slightly in the same period. It seems that in this invasion phase the population of $S$. gynobranchiata has decreased to a balance condition. There is evidence that the changing density of this species is also being affected by other biotic/abiotic factors like intra/interspecific competitors and pollutants.

RÉSUMÉ: L'abondance des populations du polychète envahissant Streblospio gynobranchiata selon les caractéristiques du sédiment sur les côtes Sud de la Mer Caspienne.

Nous avons étudié les variations saisonnières et interannuelles de la densité des populations du polychète Streblospio gynobranchiata au sud de la Mer Caspienne selon les caractéristiques du sédiment aux profondeurs de cinq et 14 mètres en 2005 et en 2010 . Aucune tendance claire n’a été identifiée pour la ligne un mais pour la ligne deux, la densité de $S$. gynobranchiata a baissé de manière significative durant toutes les saisons, excepté l'été. Les densités maximales ont été de 2040 ind. $/ \mathrm{m}^{-2}$ en 2005 et de 1013 ind. $/ \mathrm{m}^{-2}$ en 2010 . Même si le taux de matière organique totale - source de nourriture - a été plus grand en 2010, la densité de l'espèce a baissé légèrement durant l'année 2010. Il semble que, durant cette phase d'invasion, les populations étudiées ont baissé aux valeurs d'équilibre. De même, il a été suggéré que les variations de la densité de cette espèce sont contrôlées par d'autres facteurs biotiques ou abiotiques tels la concurrence intra/interspécifique et la pollution.

REZUMAT: Abundența populațională a polichetului invaziv Streblospio gynobranchiata în funcție de caracteristicile substratului în zonele costiere sudice ale Mării Caspice.

S-au cercetat variațiile sezoniere și interanuale ale densității populațiilor polichetului invaziv Streblospio gynobranchiata în sudul Mării Caspice, în funcție de caracteristicile substratului, la adâncimile de cinci respectiv 14 metri, în anii 2005 și 2010. Nu s-a evidențiat o tendință clară în variațiile densității pentru linia unu dar, pentru linia doi, densitatea $S$. gynobranchiata a scăzut semnificativ în toate anotimpurile cu excepția verii, astfel încât densităţile maxime au fost de 2040 ind. $/ \mathrm{m}^{-2}$ în 2005 și 1013 ind. $/ \mathrm{m}^{-2}$ în 2010. Deși procentul de materie organică totală utilizată ca sursă de hrană a fost mai mare în 2010, valorile densității au fost ușor mai mici în 2010. Se pare că, în această fază a invaziei, populațiile studiate au scăzut până la valori de echilibru. De asemenea, s-a sugerat că variaţiile de densitate ale acestei specii sunt controlate de alți factori biotici/abiotici, precum concurența intra/interspecifică și poluarea. 


\section{INTRODUCTION}

The success of invasive aquatic organisms is aided by a variety of attributes such as high genetic variability, wide environmental tolerance, short generation time, high reproductive capacity, early sexual maturity and a broad diet.

Normally, following some period of time after its introduction, invasive species show an exponential population increase and expansion. Maintenance of the immigrant species at a high population level will be related to interspecific competition with native species and availability of habitat, and also the availability of food. Eventually, the immigrant population may decline, for instance due to increased predation pressure, parasite infestation or loss of genetic vigour (Essink and Dekker, 2002; Neideman et al., 2003).

The south Caspian Sea, with its low diversity of macrofauna, has passed through a stressful condition during last decade. Because of the invasion of Mnemiopsis leidyi (Agassiz, 1860) and Streblospio gynobranchiata (Rice and Levin, 1998), macrofauna diversity and community structure has changed dramatically (Roohi et al., 2010; Taheri and Yazdani Foshtomi, 2011). Besides, different kinds of pollutants like heavy metals, microbial, rural and agricultural waste water are increasing in this part of the Caspian Sea (Karbassi and Amirnezhad, 2004; Fereidouni et al., 2006).

The presence of the $S$. gynobranchiata species has been found in the south-eastern United States in Florida and the Gulf of Mexico (Rice and Levin, 1998) for the first time. It was reported as an invasive species in the Black Sea (Boltacheva, 2008) and also in the Izmir Bay in 2003 (Cinar et al., 2005). In Izmir Bay (Alsancak Harbour) it became the dominant species and accounted for almost 100 percent of faunal population at some stations with a maximum density of 60,480 ind./ $/ \mathrm{m}^{-2}$ (Cinar et al., 2005, 2006). In the autumn of 2004, it was observed at Noor Coast (Iran) in the south Caspian Sea and in a short time it reached 10,311 ind. $/ \mathrm{m}^{-2}$ at 30 meters depth and became the dominant species (Taheri et al., 2009; Taheri and Yazdani Foshtomi, 2011). At Gorgan Bay on the south-east coast of the Caspian Sea, in the spring of 2010 S. gynobranchiata represented 64.80 percent of the total density of Annelida with a maximum observed density of 3,617 ind./ $\mathrm{m}^{-2}$ (Taheri et al., 2012).

Monitoring community structure is useful for coastal management and conservation. The aim of this study is to record the changing densities of $S$. gynobranchiata in the shallow water of the south Caspian Sea in the five years after its first report.

\section{MATERIAL AND METHODS}

Mazandaran Province is located in the south of the Caspian Sea along the Iranian coast. The province has a subtropical climate characterised by warm summers and mild winters. The gradient and structure of the seabed are uniform and there is almost no tidal current. The surface salinity down to 30 meters depth has negligible variations (Hadjizadeh Zaker et al., 2007). No major rivers exist in the vicinity of the sampling sites in this area though it is important to note there is rip current phenomenon in this area (Shafiei Sabet and Barani, 2011). Sampling was conducted on the Noor Coast (between Royan and Rostamrood) between $51^{\circ} 59^{\prime} 35^{\prime \prime}$ to $52^{\circ} 02^{\prime} 31^{\prime \prime} \mathrm{E}$ and $36^{\circ} 35^{\prime} 25^{\prime \prime}$ to $36^{\circ} 36^{\prime} 29^{\prime \prime} \mathrm{N}$ in 2005 and along the

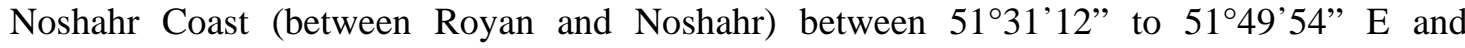
$36^{\circ} 39^{\prime} 28^{\prime \prime}$ to $36^{\circ} 35^{\prime} 11^{\prime \prime} \mathrm{N}$ in 2010 (Fig. 1). 


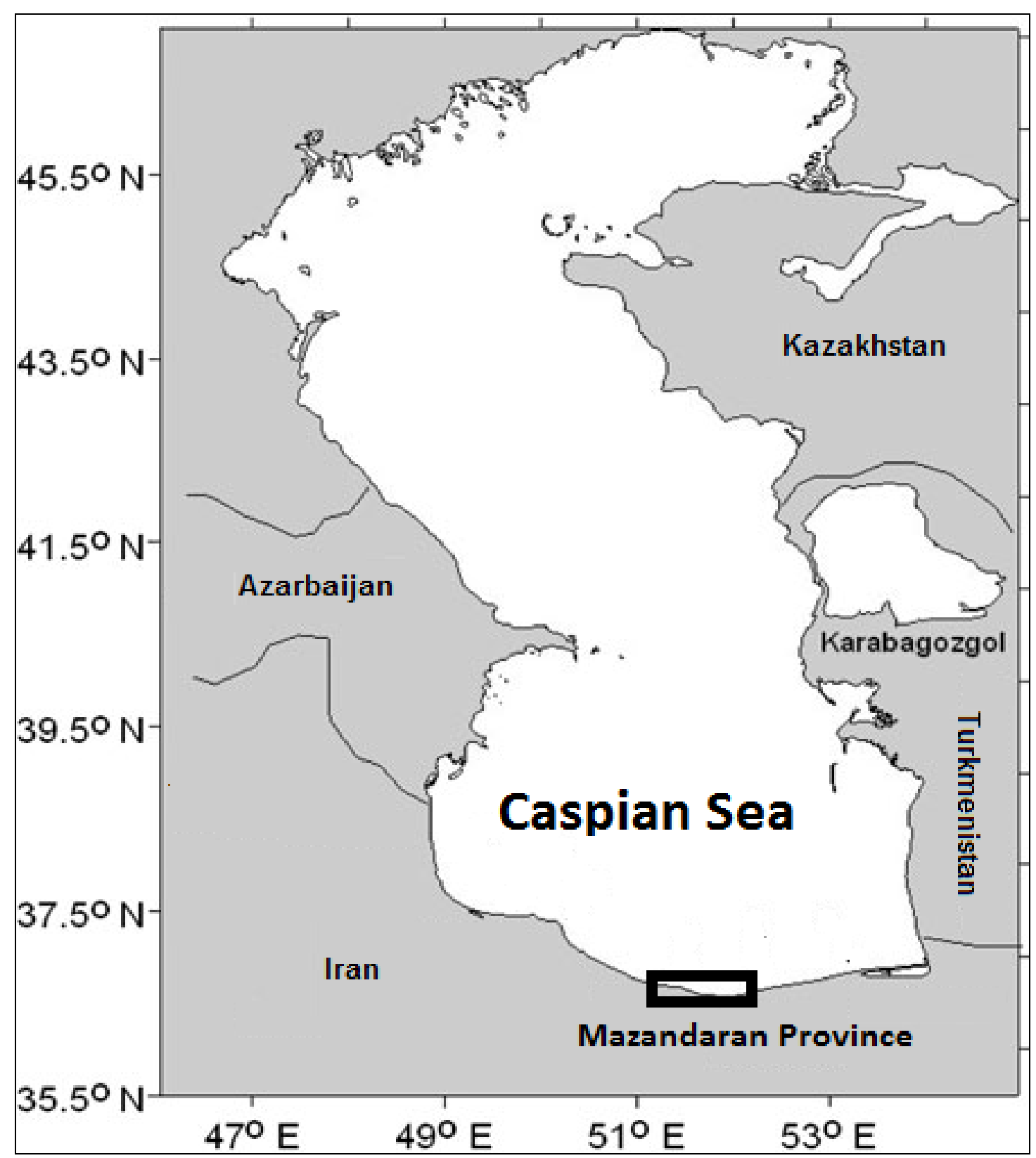

Figure 1: The map of the study area.

Seasonal samplings were carried out at two different depths (five $\mathrm{m}$ and $14 \mathrm{~m}$ ) in four transects during 2005 and 2010. At each station for the macrofauna study, three replicate samples (12 samples in each depth) were collected using a Van Veen grab $\left(250 \mathrm{~cm}^{2}\right)$. In the field, the contents of each grab were stored in separate plastic containers. Sediment from each container was gently sieved at the laboratory through a $0.5-\mathrm{mm}$ mesh and the retained material was fixed in $4 \%$ buffered formalin and stained with Rose Bengal. Then, other macrofauna was separated off and the S. gynobranchiata was collected and counted under a stereomicroscope (Taheri and Yazdani Foshtomi, 2011). Another three replicate sediment samples were taken at 
each station to measure the percentage of the total organic matter (TOM), again using the Van Veen grab. The surface sediment (four $\mathrm{cm}$ ) was sub-sampled and stored in clean plastic containers. Total organic matter was determined by loss weight on ignition (four hours at $550^{\circ} \mathrm{C}$ ) after drying ( 24 hours at $90^{\circ} \mathrm{C}$ ) to a constant weight (Taheri et al., 2012).

Our sampling design provided measurements in two years, four seasons in each year, and 12 samples at each depth. To test for differences in density (univariate) between different seasons and depths, a fully-crossed, three-factor-design was analysed using PERMANOVA. The design included the random factor replicate nested in the fixed factor season, and the fixed factor depth on year. A Euclidean distance-resemblance-matrix was used for similarity matrix. Whenever significant differences were observed, pairwise tests were performed to investigate differences. P-values were obtained from P perm and Monte Carlo P (MC) (Anderson and Robinson, 2003). These analyses were carried out using PRIMER v6 with PERMANOVA+ add-on. All figures were drawn using Excel. Furthermore, correlations between density and sediment variables were tested with Spearman's rank.

\section{RESULTS}

In all seasons the percentage of total organic matter (TOM) increased with depth ( $\mathrm{p}=$ $0.00)$. At a five-meters depth, the highest and lowest TOM values were obtained in summer and winter, respectively. At a 14-meters depth the highest value was observed in autumn while the lowest occurred in the summer. In 2010, although the percentage of TOM increased with depth, there were no seasonal differences at both depths. Inter-annual comparisons showed a clear increase in S. gynobranchiata at both depths in all seasons $(\mathrm{p}=0.00)$.

During the 2005 sampling period the percentage of sand decreased with depth $(\mathrm{p}=$ 0.00 ). There were no seasonal differences in the amount of sand at the five-meters depth but at 14 meters the highest values of sand occurred in spring and summer and the lowest was in the winter. In 2010, sand was also found to decrease with depth $(p=0.01)$ and there were no seasonal differences. Inter-annual comparisons only showed variations in the amount of sand at the five-meters depth except in spring $(\mathrm{p}=0.01)$.

The percentage of silt-clay did not show differences at the five-meters depth in 2005. The greatest amounts of silt-clay were obtained in the winter and autumn while the least amount was obtained in the summer. Furthermore, the amount of slit-clay decreased with depth $(p=0.00)$. In 2010 , it decreased with depth $(p=0.01)$ with no differences due to seasonality. The inter-annual comparison only showed variations at the five-meters depth except in spring ( $\mathrm{p}=0.01$, Tab. 1 ).

A significant difference in the density of $S$. gynoranchiata was observed in the different seasons during 2005. In line one, the maximum density (144.44 ind./ $\left./ \mathrm{m}^{-2}\right)$ was observed in summer and autumn while the minimum density was observed $\left(0\right.$ ind. $\left./ \mathrm{m}^{-2}\right)$ in winter. In line two, the lowest density was obtained in summer $\left(825.93 \mathrm{ind} . / \mathrm{m}^{-2}\right)$ and the highest density was obtained in spring. Also, S. gynoranchiata densities increased with depth $(p=0.00)$. In 2010 at both depths, the highest density occurred in summer (233.33 and $1,013.89$ ind. $\left./ \mathrm{m}^{-2}\right)$ while the lowest density was found in the spring ( 0 and $\left.11.11 \mathrm{ind} . / \mathrm{m}^{-2}\right)$. With the exception of spring, density increased with depth in all seasons $(p=0.00)$. An interannual comparison in line one showed a higher value in winter $2010(\mathrm{p}=0.01)$ and a lower value in autumn 2005 ( $\mathrm{p}=0.00$ ) while in line two, except summer in other seasons, density was higher in $2005(\mathrm{p}=0.00)$. The range of density in 2005 was between $0-144.44 \mathrm{ind} . / \mathrm{m}^{-2}$ and 825.59-2040.74 ind. $/ \mathrm{m}^{-2}$ in five-and-14-meter depths respectively. In 2010 the range of density was between 0 to 233.33 ind. $/ \mathrm{m}^{-2}$ and 11.11 to $1,013.89$ ind.$/ \mathrm{m}^{-2}$ in the similar depths. In general, total density decreased in 2010 (Fig. 2). 
Table 1: Sediment variables during study; upper case letters show seasonal variation.

\begin{tabular}{|c|l|l|l|l|l|}
\hline TOM & \multicolumn{1}{|c|}{ Year } & \multicolumn{1}{c|}{ Winter } & \multicolumn{1}{c|}{ Spring } & \multicolumn{1}{c|}{ Summer } & \multicolumn{1}{c|}{ Autumn } \\
\hline TOM 5 & 2005 & $1.66 \pm 0.21^{\mathrm{C}}$ & $2.32 \pm 0.44^{\mathrm{B}}$ & $2.73 \pm 0.27^{\mathrm{A}}$ & $2.35 \pm 0.17^{\mathrm{B}}$ \\
meters & 2010 & $4.80 \pm 0.71^{\mathrm{A}}$ & $5.62 \pm 1.21^{\mathrm{A}}$ & $4.84 \pm 1.22^{\mathrm{A}}$ & $5.32 \pm 0.94^{\mathrm{A}}$ \\
\hline TOM 14 & 2005 & $2.90 \pm 0.92^{\mathrm{AB}}$ & $3.38 \pm 0.21^{\mathrm{B}}$ & $3.53 \pm 0.15^{\mathrm{C}}$ & $2.83 \pm 0.14^{\mathrm{A}}$ \\
meters & 2010 & $6.64 \pm 1.37^{\mathrm{A}}$ & $6.33 \pm 1.17^{\mathrm{A}}$ & $6.30 \pm 1.77^{\mathrm{A}}$ & $5.83 \pm 0.78^{\mathrm{A}}$ \\
\hline Sand 5 & 2005 & $97.46 \pm 1.14^{\mathrm{A}}$ & $97.46 \pm 0.61^{\mathrm{A}}$ & $97.59 \pm 0.45^{\mathrm{A}}$ & $97.70 \pm 0.67^{\mathrm{A}}$ \\
meters & 2010 & $92.41 \pm 5.11^{\mathrm{A}}$ & $97.50 \pm 2.07^{\mathrm{A}}$ & $92.68 \pm 4.24^{\mathrm{A}}$ & $93.03 \pm 5.48^{\mathrm{A}}$ \\
\hline Sand 14 & 2005 & $78.92 \pm 14.49^{\mathrm{C}}$ & $93.44 \pm 0.89^{\mathrm{A}}$ & $92.98 \pm 1.61^{\mathrm{A}}$ & $90.93 \pm 1.39^{\mathrm{B}}$ \\
meters & 2010 & $75.95 \pm 13.72^{\mathrm{A}}$ & $89.60 \pm 7.53^{\mathrm{A}}$ & $87.67 \pm 8.63^{\mathrm{A}}$ & $96.15 \pm 0.68^{\mathrm{A}}$ \\
\hline Silt-clay 5 & 2005 & $2.57 \pm 0.61^{\mathrm{A}}$ & $2.38 \pm 0.35^{\mathrm{A}}$ & $2.62 \pm 0.90^{\mathrm{A}}$ & $2.30 \pm 0.26^{\mathrm{A}}$ \\
meters & 2010 & $6.95 \pm 2.87^{\mathrm{A}}$ & $1.57 \pm 0.72^{\mathrm{A}}$ & $5.16 \pm 4.80^{\mathrm{A}}$ & $6.26 \pm 2.40^{\mathrm{A}}$ \\
\hline Silt-clay & 2005 & $15.65 \pm 7.62^{\mathrm{A}}$ & $6.43 \pm 0.80^{\mathrm{AB}}$ & $5.48 \pm 1.04^{\mathrm{B}}$ & $7.39 \pm 0.63^{\mathrm{A}}$ \\
14 meters & 2010 & $20.32 \pm 7.18^{\mathrm{A}}$ & $9.92 \pm 3.88^{\mathrm{A}}$ & $11.16 \pm 4.49^{\mathrm{A}}$ & $2.09 \pm 0.50^{\mathrm{A}}$ \\
\hline
\end{tabular}

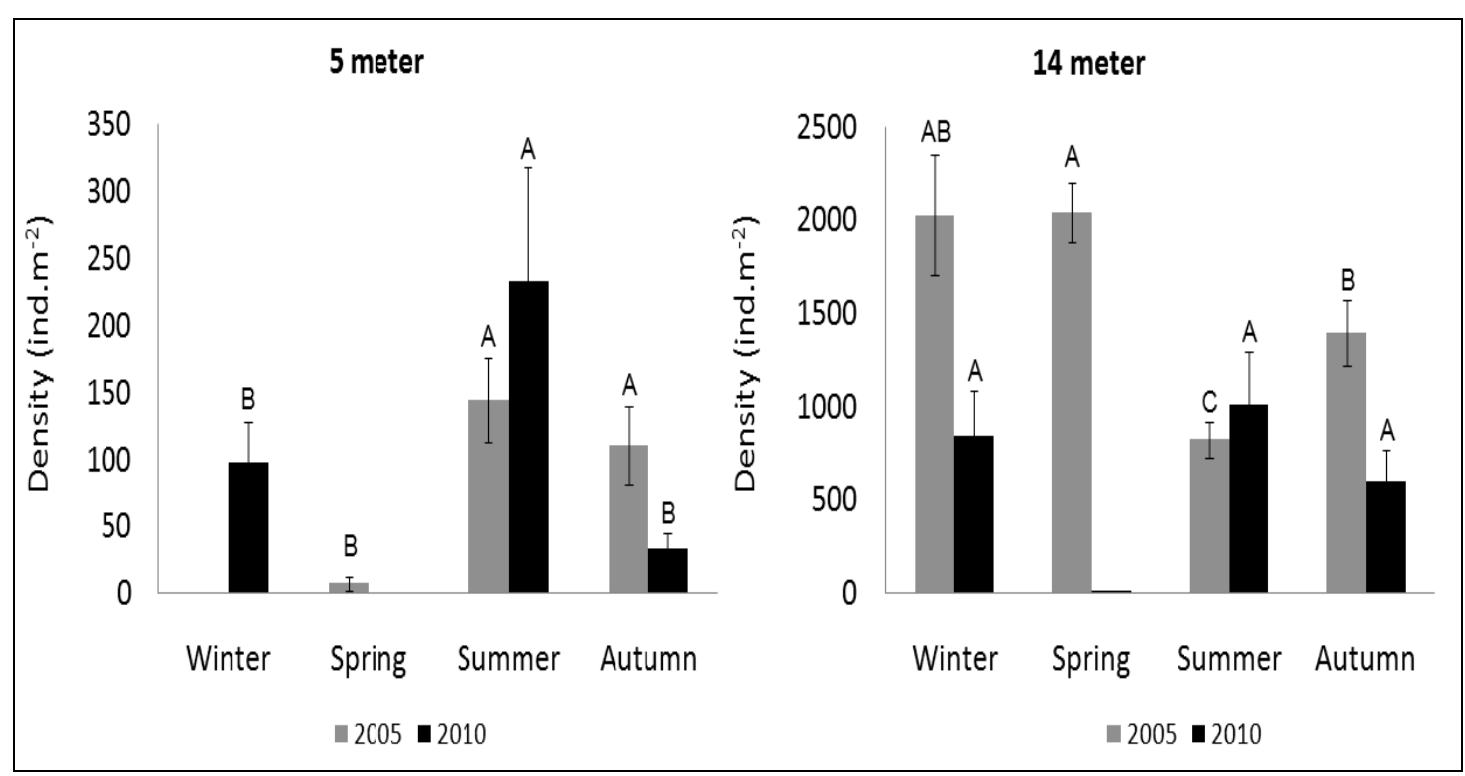

Figure 2: Density (mean \pm SE) of S. gynobranchiata during the sampling periods.

Upper case letters show seasonal variation.

In case of Spearman's rank correlation coefficient between density of S. gynobranchiata with sediment variables (Tab. 2), variable TOM showed a relationship with density.

Table 2: Spearman's rank correlation coefficient between density of S. gynobranchiata with sediment variables; *, $\mathrm{P}<0.05, * *, \mathrm{P}<0.01$.

\begin{tabular}{|l|c|c|c|c|}
\hline & Winter & Spring & Summer & Autumn \\
\hline TOM 5 meters & $0.632^{* *}$ & 0.109 & 0.047 & -0.273 \\
\hline TOM 14 meters & $-0.457^{*}$ & $-0.750^{* *}$ & -0.040 & $-0.454^{*}$ \\
\hline Sand 5 meters & 0.462 & 0.472 & 0.065 & 0.067 \\
\hline Sand 14 meters & 0.215 & 0.217 & -0.274 & $-0.512^{*}$ \\
\hline Silt-clay 5 meters & 0.330 & 0.287 & -0.095 & 0.066 \\
\hline Silt-clay 14 meters & 0.156 & -0.131 & 0.162 & 0.397 \\
\hline
\end{tabular}




\section{DISCUSSION}

Invasive species are considered a major global threat to the diversity and integrity of marine ecosystems (Norkko et al., 2011). It is often difficult to accurately assess the long-term effects of invaders because of the lack of data and the changing nature of ecosystems. However, existing historical information can be used to make a comparison with current conditions and generate hypotheses that can be tested experimentally (Crooks, 2001).

S. gynobranchiata has recently been observed in the south Caspian Sea (Taheri et al., 2009) and after discovery it became the dominant species of macrofauna in that area (Taheri and Yazdani Foshtomi, 2011). The present study shows that the density of S. gynobranchiata decreased between 2005-2010 with densities of 2,040 and 1,013 ind. $/ \mathrm{m}^{2}$ in 2005 and 2010 respectively. In Izmir Bay (Alsancak Harbour) S. gynobranchiata was a dominating species with a maximum density reported at 60,480 ind. $/ \mathrm{m}^{-2}$ (Cinar et al., 2005, 2006). The maximum density recorded reached to $10,311.11$ ind. $/ \mathrm{m}^{-2}$ at a 30 meters depth along the Noor Coast. Generally, the density and biomass of $S$. gynobranchiata increased as the water became deeper while the amount of total organic matter and percentage of sand decreased (Taheri et al., 2009). S. gynobranchiata was the dominant species with 84.95 percent of the total density of macrofauna (Taheri and Yazdani Foshtomi, 2011). In spring 2010 at the Gorgan Bay (in the south east of the Caspian Sea), S. gynobranchiata was 64.80 percent of the total density of Annelida which represents its maximum density observed 3,617 ind. $/ \mathrm{m}^{-2}$.

Seasonal density variations did not show a regular trend in both years, but with increasing water depth the density of S. gynobranchiata increased. In 2005, there was a significant correlation between the densities of $S$. gynobranchiata with the percentage of TOM but in 2010 there was a significant correlation only in winter.

After the invasion of $M$. leidyi in the southern Caspian Sea, biodiversity of phytoplankton has changed (Roohi et al., 2010) and chlorophyll levels have increased (Kideys et al., 2008). Because phytoplanktons are the most important source of TOM in the south Caspian Sea (Lahijani, 2004), increases in chlorophyll could be the cause of the increasing percentage of TOM in 2010. In both 2005 and 2010, the percentage of TOM increased as the water got deeper. Because S. gynobranchiata is a deposit feeder (Cinar et al., 2005), higher densities of it found in deeper water may be related to the increased percentage of TOM (as a food). Taheri et al. (2009) showed that the density of S. gynobranchiata is positively correlated with the percentage of TOM. Higher densities of $S$. shrubsolii and $S$. benedictii have also been reported with an increase in TOM (Rossi and Lardiccii, 2002; Garcia-Arberas and Rallo, 2004). But the strangest thing is why the density of S. gynobranchiata did not increase in 2010 while the percentage of total organic matter increased?

The south Caspian Sea has a lot of different pollutants like heavy metals (Karbassi and Amirnezhad, 2004), microbial pollutants (Fereidouni et al., 2006), and rural and agricultural waste water. These contaminants continue to increase in this part of the world and certainly pollution can have a bad effect on macrofauna. In the Gorgan Bay, there was no significant correlation between the density of Annelid and several environmental conditions (Taheri et al., 2011), so it seems there are other factors controlling benthic fauna in the south Caspian Sea.

The backwash power of a rip current has an effect on surface sediment and transports fine sediment (MacMahan et al., 2005). Rip currents can also wash the meiofauna and macrofauna out to deeper areas (McLachlan and Hesp, 1984), which can be a reason for higher densities in deeper water. Furthermore, rip currents can wash away TOM and indirectly affect the availability of organic matter used as food for macrofauna. Hence, it could be said that the effect of the rip current on sediment, TOM and washing macrofauna and their larvae is another reason explaining increasing density with increasing depth. 


\section{CONCLUSIONS}

Although the percentage of total organic matter as a food source has increased since 2005, 2010 results show the density of S. gynobranchiata has decreased slightly since 2005 . So it seems that in the invasion phase the population of $S$. gynobranchiata has decreased to a balance condition. Besides this, it is suggested that the changing density of this species is controlled by other biotic/abiotic factors like intra/interspecific competitions and pollutants. More information about the macrofauna community and environmental variables are needed, however, to increase our understanding of the changing population of S. gynobranchiata.

\section{ACKNOWLEDGEMENTS}

The authors are so thankful to all members of the Iranian National Institute for Oceanography for their assistance. Special thanks are due to Benmar T. F. who checked and improved the English.

\section{REFERENCES}

1. Anderson M. J. and Robinson J., 2003 - Generalized discriminant analysis based on distances, Australian and New Zealand Journal of Statistics, 45, 301-318.

2. Boltacheva N. A., 2008 - Finding of new alien species Streblospio gynobranchiata Rice and Levin, 1998 (Polychaeta: Spionidae) in the Black Sea, Marine Ecological Journal, 7, 4, 12-13.

3. Cinar M. E., Ergen Z., Dagli E. and Petersen M. E., 2005 - Alien species of spionid polychaetes (Streblospio gynobranchiata and Polydora cornuta) in Izmir Bay, Mediterranean, Journal of the Marine Biological Association of the United Kingdom, 85, 821-827.

4. Cinar M. E., Katagan T., Ozturk B., Egemen O., Ergen Z., Kocatas A., Onen M., Kirkim F., Bakir K., Kurt G., Dagli E., Kaymakci A., Acik C., Dogan A. and Ozcan T., 2006 - Temporal changes of soft-bottom zoobenthic communities in and around Alsancak Harbour (Izmir Bay, Aegean Sea), with special attention to the autecology of exotic species, Marine Ecology, 27, 229-246.

5. Crooks J. A., 2001 - Assessing invader roles within changing ecosystems: historical and experimental perspectives on an exotic mussel in an urbanized lagoon, Biological Invasions, 3, 23-36.

6. Essink K. and Dekker R., 2002 - General patterns in invasion ecology tested in the Dutch Wadden Sea: the case of a brackish-marine Polychaetous worm, Biological Invasions, 4, 359368.

7. Fereidouni S., Modir Rousta H. and Azin F., 2006 - The First Report of Avian Cholera in Miankaleh Wetland, Southeast Caspian Sea, Podoces, 1, 71-75.

8. Garcia-Arberas L. and Rallo A., 2004 - Population dynamics and production of Streblospio benedicti (Polychaeta) in a non-polluted estuary on the Basque coast (Gulf of Biscay), Scientia Marina, 68, 2, 193-203.

9. Hadjizadeh Zaker N., Ghafari P. and Jamshidi S., 2007 - Physical study of the southern coastal waters of the Caspian Sea, off Babolsar, Mazandaran in Iran, Journal of Coastal Research, 50, 564-569.

10. Karbassi A. R. and Amirnezhad R., 2004 - Geochemistry of heavy metals and sedimentation rate in a bay adjacent to the Caspian Sea, International Journal of Environmental Science and Technology, 1, 191-198.

11. Kideys A. E., Roohi A., Eker-Develi E., Mélin F. and Beare D., 2008 - Increased Chlorophyll Levels in the Southern Caspian Sea Following an Invasion of Jellyfish, Research Letters in Ecology Article, ID 185642, 4.

12. Lahijani H., 2004 - Introduction to Caspian Sea characteristics, Noorbakhsh Press, 119.

13. MacMahan J. H., Thornton E. B., Stanton T. P. and Reniers H. M., 2005 - RIPEX: observation of a rip current system, Marine Geology, 218, 113-134. 
14. McLachlan A. and Hesp P., 1984 - Faunal response to morphology and water circulation of a sandy beach with cusps, Marine Ecology Progress Series, 19, 133-144.

15. Neideman R., Wenngren J. and Ólafsson E., 2003 - Competition between the introduced polychaete Marenzelleria sp. and the native amphipod Monoporeia affinis in Baltic soft bottoms, Marine Ecology Progress Series, 264, 49-55.

16. Norkko J. Reed D. C., Timmermann K., Norkko A., Gustafsoon B. G., Bonsdorff E., Slomp C. P., Carstensen J. and Conley D. J., 2011 - A welcome can of worms? Hypoxia mitigation by an invasive species, Global Change Biology, 18, 2, 422-434.

17. Rice A. S. and Levin L. A., 1998 - Streblospio gynobranchiata, a new spionid polychaete species (Annelida: Polychaeta) from Florida and the Gulf of Mexico with an analysis of phylogenetic relationships within the genus Streblospio, Proceeding of the Biological Society of Washington, 111, 694-707.

18. Roohi A., Kideys A. E., Sajjadi A., Hashemian A., Pourgholam R., Fazli H., Khanari A. and Eker-Develi E., 2010 - Changes in biodiversity of phytoplankton, zooplankton, fishes and macrobenthos in the Southern Caspian Sea after the invasion of the ctenophore Mnemiopsis Leidyi, Biological Invasions, 12, 2343-2361.

19. Rossi F. and Lardiccii C., 2002 - Role of nutritive value of sediment in regulating population dynamics of the deposit-feeding Polychaeta streblospio shrubsolii, Marine Biology, 140, 11291138.

20. Shafiei Sabet B. and Barani G. A., 2011 - Field investigation of rip currents along the southern coast of the Caspian Sea, Scientia Iranica, 18, 4, 878-884.

21. Taheri M., Seyfabadi J., Abtahi B. and Yazdani Foshtomi M., 2009 - Population changes and reproduction of an alien spionid polychaete, Streblospio gynobranchiata, in shallow waters of the south Caspian Sea, Marine Biodiversity Records, 2, 40.

22. Taheri M. and Yazdani Foshtomi M., 2011 - Community structure and biodiversity of shallow water macrobenthic fauna at Noor coast, South Caspian Sea, Iran, Journal of the Marine Biological Association of the United Kingdom, 91, 607-613.

23. Taheri M., Yazdani Foshtomi M., Noranian M. and Mira S. S., 2011 - Annelida Community Structure in the Gorgan Bay, Southeast of Caspian Sea, Iran - A Case Study, World Journal of Fish and Marines Sciences, 3, 5, 414-421.

24. Taheri M., Yazdani Foshtomi M., Noranian M. and Mira S. S., 2012 - Spatial Distribution and Biodiversity of Macrofauna in the Southeast of the Caspian Sea, Gorgan Bay in Relation to Environmental Conditions, Ocean Science Journal, 47, 2, 113-122. 